\title{
Arctic Ocean Warming Contributes to Reduced Polar Ice Cap
}

\author{
Igor V. Polyakov, ${ }^{\mathrm{a}}$ LeOnid A. Timokhov, ${ }^{\mathrm{b}}$ Vladimir A. AleXeev, ${ }^{\mathrm{a}}$ Sheldon Bacon, ${ }^{\mathrm{c}}$ \\ IGOR A. DMitrenko, ${ }^{\mathrm{d}}$ LOUIS Fortier, ${ }^{\mathrm{e}}$ IVAN E. Frolov, ${ }^{\mathrm{b}}$ JEAN-ClAude GASCARD, ${ }^{\mathrm{f}}$ EdMOND HANSEN, ${ }^{\mathrm{g}}$

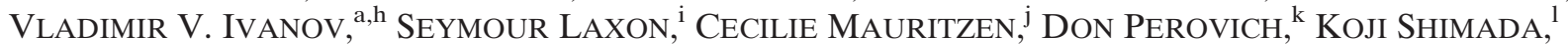 \\ HARPer L. Simmons, ${ }^{a}$ Vladimir T. SOKOlov, ${ }^{\mathrm{b}}$ Michael STEEle, ${ }^{\mathrm{m}}$ AND JOHN TOOLE ${ }^{\mathrm{n}}$ \\ ${ }^{a}$ International Arctic Research Center, University of Alaska Fairbanks, Fairbanks, Alaska \\ ${ }^{\mathrm{b}}$ Arctic and Antarctic Research Institute, St. Petersburg, Russia \\ ${ }^{\mathrm{c}}$ National Oceanography Centre, Southampton, United Kingdom \\ ${ }^{\mathrm{d}}$ Leibniz Institute of Marine Sciences, University of Kiel, IFM-GEOMAR, Kiel, Germany \\ e Québec-Océan and ArcticNet, Université Laval, Quebec City, Quebec, Canada \\ ${ }^{\mathrm{f}}$ LOCEAN, Pierre and Marie Curie University, Paris, France \\ ${ }^{g}$ Norwegian Polar Institute, Troms $\varnothing$, Norway \\ ${ }^{\mathrm{i}}$ University College London, London, United Kingdom \\ ${ }^{\mathrm{j}}$ Norwegian Meteorological Institute, Oslo, Norway \\ ${ }^{\mathrm{k}}$ Cold Regions Research and Engineering Laboratory, Hanover, New Hampshire \\ ${ }^{1}$ Tokyo University of Marine Science and Technology, Tokyo, Japan \\ ${ }^{\mathrm{m}}$ Polar Science Center, Applied Physics Lab, University of Washington, Seattle, Washington \\ ${ }^{\mathrm{n}}$ Woods Hole Oceanographic Institution, Woods Hole, Massachusetts
}

(Manuscript received 19 August 2009, in final form 16 August 2010)

\begin{abstract}
Analysis of modern and historical observations demonstrates that the temperature of the intermediatedepth (150-900 m) Atlantic water (AW) of the Arctic Ocean has increased in recent decades. The AW warming has been uneven in time; a local $\sim 1^{\circ} \mathrm{C}$ maximum was observed in the mid-1990s, followed by an intervening minimum and an additional warming that culminated in 2007 with temperatures higher than in the 1990 s by $0.24^{\circ} \mathrm{C}$. Relative to climatology from all data prior to 1999 , the most extreme 2007 temperature anomalies of up to $1^{\circ} \mathrm{C}$ and higher were observed in the Eurasian and Makarov Basins. The AW warming was associated with a substantial (up to 75-90 m) shoaling of the upper AW boundary in the central Arctic Ocean and weakening of the Eurasian Basin upper-ocean stratification. Taken together, these observations suggest that the changes in the Eurasian Basin facilitated greater upward transfer of AW heat to the ocean surface layer. Available limited observations and results from a 1D ocean column model support this surmised upward spread of AW heat through the Eurasian Basin halocline. Experiments with a 3D coupled ice-ocean model in turn suggest a loss of $28-35 \mathrm{~cm}$ of ice thickness after $\sim 50 \mathrm{yr}$ in response to the $0.5 \mathrm{~W} \mathrm{~m}^{-2}$ increase in AW ocean heat flux suggested by the 1D model. This amount of thinning is comparable to the $29 \mathrm{~cm}$ of ice thickness loss due to local atmospheric thermodynamic forcing estimated from observations of fast-ice thickness decline. The implication is that AW warming helped precondition the polar ice cap for the extreme ice loss observed in recent years.
\end{abstract}

\footnotetext{
${ }^{\mathrm{h}}$ Additional affiliations: Arctic and Antarctic Research Institute, St. Petersburg, Russia, and Scottish Marine Institute, SAMS, Oban, United Kingdom.
}

Corresponding author address: Igor V. Polyakov, International Arctic Research Center, University of Alaska Fairbanks, Fairbanks, AK 99709.

E-mail: igor@iarc.uaf.edu

\section{Introduction}

Arctic sea ice has undergone substantial changes in recent decades (e.g., Parkinson et al. 1999; Walsh and Chapman 2001; Meier et al. 2007; Fig. 1), culminating in summer 2007 when the seasonal ice retreat broke all records in the history of instrumental observations (e.g., Comiso et al. 2008; Stroeve et al. 2008). 


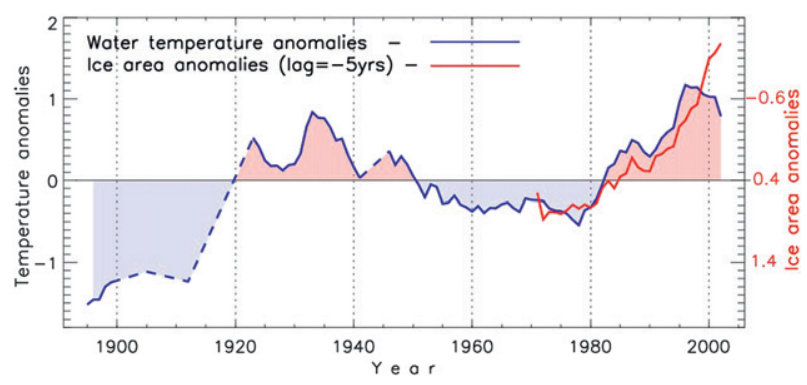

FIG. 1. Seven-year running mean normalized Atlantic water (AW) temperature anomalies [dashed segments represent gaps in the record, adapted from Polyakov et al. (2004)] and September Arctic ice area anomalies $\left[10^{6} \mathrm{~km}^{2}\right.$; reverse vertical axis is used, lagged by $5 \mathrm{yr}$; courtesy National Snow and Ice Data Center (NSIDC) and International Arctic Research Center (IARC)-Japan Aerospace Exploration Agency (JAXA) Information System (IJIS)].

Although anomalous atmospheric forcing clearly was an important factor in the 2007 sea ice reduction (e.g., Zhang et al. 2008), the changes might not have been as dramatic if the Arctic ice had not been weakened over the last several decades. A 1-m thinning of centralbasin sea ice over 11 years has been reported (Rothrock et al. 2003). In addition to this thinning, the perennial ice fraction observed in March declined from roughly $5.5 \times 10^{6} \mathrm{~km}^{2}$ in 1970 to $4.0 \times 10^{6} \mathrm{~km}^{2}$ in 2002 to $2.6 \times$ $10^{6} \mathrm{~km}^{2}$ in 2007 (Nghiem et al. 2007). This observed Arctic sea ice reduction resulted from a complex interplay between the dynamics and thermodynamics of the atmosphere, sea ice, and ocean. For example, enhanced upper-ocean solar heating through leads and consequent ice bottom melting were observed in the Beaufort Sea in summer 2007 (Perovich et al. 2008; Toole et al. 2010).
Deep-ocean heat, on the other hand, has not been widely considered to be an important contributor to the shrinking Arctic sea ice because of the insulating nature of the halocline layer. Throughout much of the Arctic, a cap of relatively fresh, cold surface water is observed, bounded below by a strong pycnocline in which salinity increases from values of 33 psu or lower to around 34.8 psu at $200-300-\mathrm{m}$ depth. This stratification has been believed to effectively insulate the ocean surface layer and pack ice from the heat carried by the relatively warm intermediate waters (Rudels et al. 1996).

There are, however, arguments in support of an important role for oceanic heat in shaping the Arctic pack ice. They are often keyed to the presence of warm $\left(>0^{\circ} \mathrm{C}\right)$ intermediate-depth (150-900 m) water of Atlantic origin [the so-called "Atlantic Water" (AW)]. Entering the Arctic between Greenland and Europe and flowing cyclonically along the basin margins (e.g., Rudels et al. 1994), AW carries a vast amount of heat. Until recently, maximum $\left(\sim 2^{\circ}-3^{\circ} \mathrm{C}\right) \mathrm{AW}$ temperatures have been found in the Nansen Basin, while in the Canadian Basin the AW temperature has remained near $0.5^{\circ} \mathrm{C}$ (Fig. 2a). This decrease of AW temperature with distance from its Arctic entrance region implies that AW heat must be lost along the AW spreading pathways. Some of this AW heat is believed to be lost to the overlying halocline waters (e.g., Rudels et al. 1996; Steele and Boyd 1998; Martinson and Steele 2001). Estimates of upward heat flux from the AW yield values ranging from $1.3 \mathrm{~W} \mathrm{~m}^{-2}$ (analytical model, Rudels et al. 1996), to $2.1 \mathrm{~W} \mathrm{~m}^{-2}$ (1D mixed layer model, Steele and Boyd 1998), to 3-4 $\mathrm{W} \mathrm{m}^{-2}$ (parameterization for the bulk heat transfer coefficient from the mixed layer temperature, Krishfield and Perovich 2005), to as high
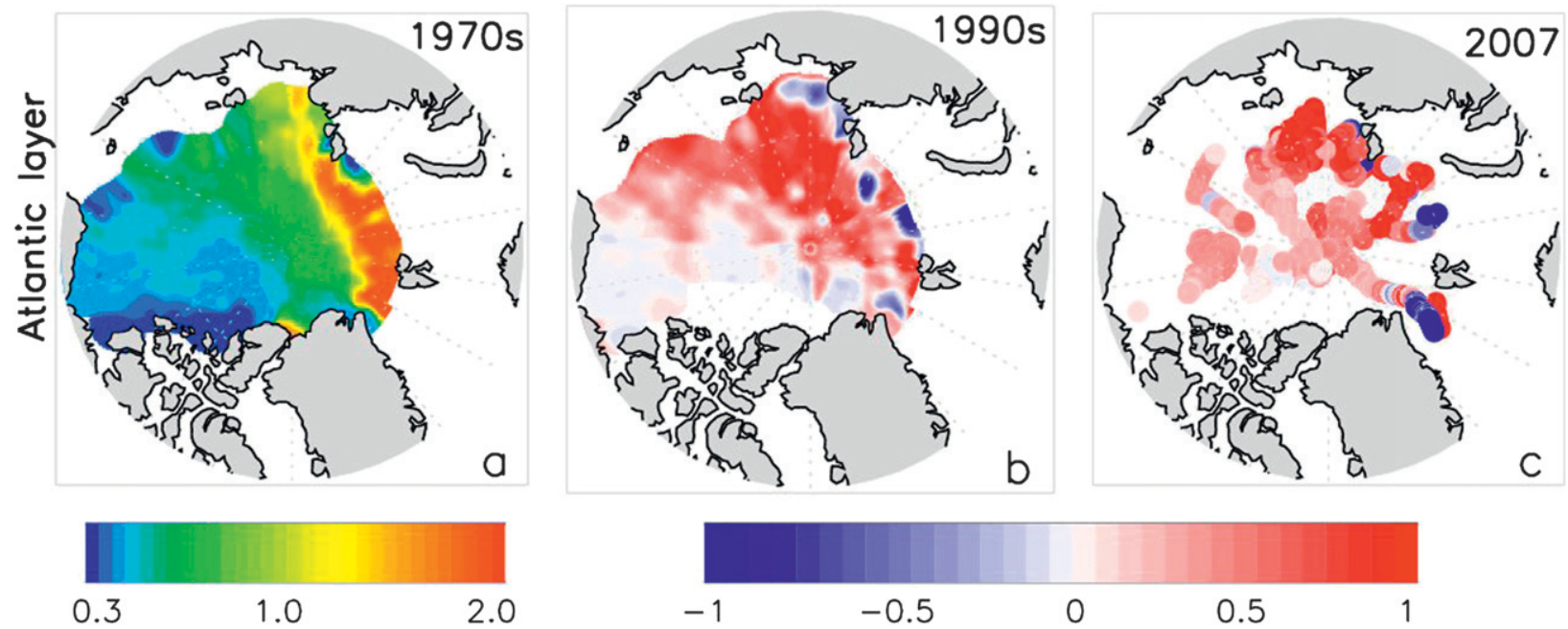

FIG. 2. (a) Mean AW temperature $\left({ }^{\circ} \mathrm{C}\right)$ averaged over the 1970 s; AW temperature (b) anomalies $\left({ }^{\circ} \mathrm{C}\right)$ averaged over the 1990 s and $(\mathrm{c})$ for data from 2007. Anomalies are computed relative to climatology shown in (a). 
as $4-6 \mathrm{~W} \mathrm{~m}^{-2}$ (heat budget estimates for the eastern Nansen Basin, Walsh et al. 2007).

The diversity of these previous oceanic heat flux estimates may be partially attributed to strong high-latitude temporal variability (e.g., Polyakov and Johnson 2000). Over the twentieth century, the AW temperature record shows two warmer periods, in the 1930s-40s and in recent decades, and two colder periods, early in the century and in the 1960s-70s (Polyakov et al. 2004, Fig. 1). Observations from the 1990 s documented positive AW temperature anomalies of up to $1^{\circ} \mathrm{C}$ relative to temperatures measured in the 1970s throughout vast areas of the Eurasian and Makarov Basins (Quadfasel et al. 1991; Carmack et al. 1995; Swift et al. 1997; Morison et al. 1998; Steele and Boyd 1998; Polyakov et al. 2004Fig. 2b). The AW warming slowed or reversed slightly in the late 1990s (Boyd et al. 2002), but remnants of this signal arrived in the Canadian Basin in the early 2000s (Shimada et al. 2004). Observations from the 2000s documented another large-scale warming of the AW layer of the Eurasian Basin (Polyakov et al. 2005; Dmitrenko et al. 2008b). Most notably, data collected in 2006 in the vicinity of Svalbard at $\sim 30^{\circ} \mathrm{E}$ show AW temperatures with a magnitude unprecedented in the history of regional instrumental observations (Ivanov et al. 2009).

What impact do these temperature changes have on the upward flux of AW heat and, in turn, on the sea ice? Here we utilize a vast collection of observational data, including those data collected in 2007 under the auspices of the International Polar Year (IPY), to investigate the possible relationships between AW temperatures, upperocean stratification, the vertical ocean heat flux, and the sea ice cover. Observation-based findings are complemented by modeling results so as to quantify impacts of these changes on the high-latitude polar ice cap.

\section{Observational data and models}

\section{a. Observational data}

The observational historical database used in this study includes datasets previously used to study longterm variations of the AW temperature (Polyakov et al. 2004) and of freshwater content of the Arctic Ocean (Polyakov et al. 2008). Most observations prior to the 1980s were obtained from Nansen bottle water samples and discrete temperature measurements. Although these data have rather coarse vertical resolution, they span a reasonable horizontal extent (sufficient for the present research); multiyear coverage makes them an invaluable resource for understanding interannual variations of the water-mass structure within the Arctic Ocean. Typical measurement errors are $0.01^{\circ} \mathrm{C}$ for temperature and 0.02 for titrated salinity.

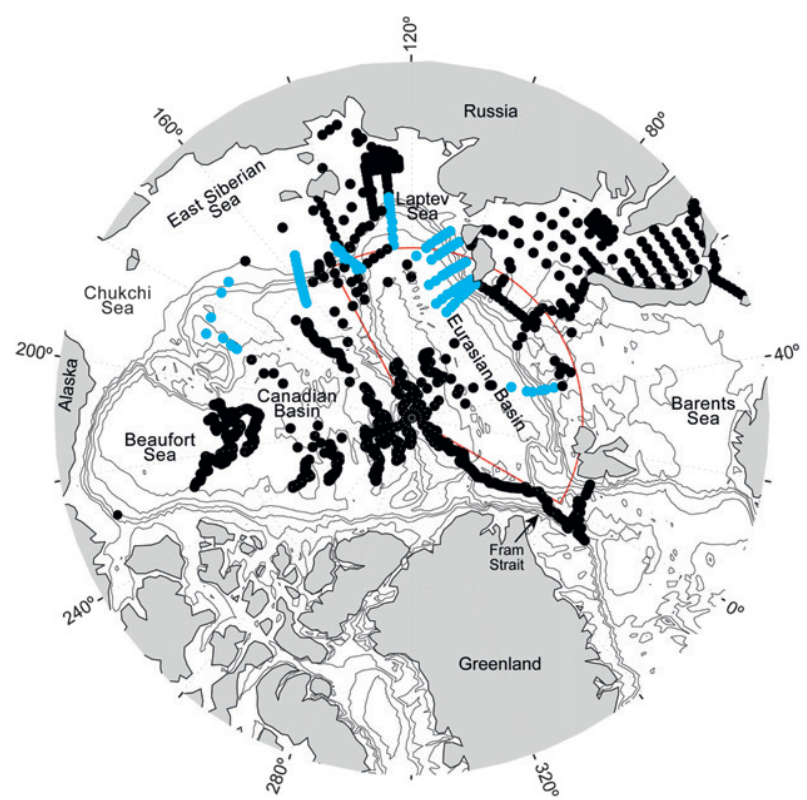

FIG. 3. Map showing locations of oceanographic stations carried out in 2007. Data from stations marked by blue dots form 10 oceanographic cross sections used for analysis of heat content and upward spread of AW heat. The red line shows the Eurasian Basin subregion used to estimate ocean stratification and vertical heat fluxes.

In recent years, observations have been made using conductivity-temperature-depth (CTD) instruments that, along with improved water sample analysis and calibration techniques, has resulted in accuracies and vertical resolution at least an order of magnitude greater than that of the historical measurements. The dataset that we analyzed for 2007 consists of 3452 temperature and salinity profiles (Fig. 3). This dataset is dominated by summer ship-based observations; however, drifting buoys provide valuable central-basin data coverage in winter months. These historical and modern profile data were used to estimate anomalies in upper-ocean buoyancy frequency and, through application of simple models, infer variations in vertical heat flux. For the Eurasian Basin subregion $\left(80^{\circ}-90^{\circ} \mathrm{N}, 0^{\circ}-150^{\circ} \mathrm{E}\right)$, data from 2621 historical oceanographic stations were available; 1584 temperature and salinity profiles were acquired in this region in 2007. The continental slope subregion (same longitude range, south of $84^{\circ} \mathrm{N}$ ) was sampled by 1993 historical stations and at 490 sites in 2007.

Decadal-mean model-based vertical heat flux estimates for the Eurasian Basin are based on data from 775 and 330 oceanographic stations occupied in the 1970s and 1990s, respectively. The climatology used to calculate AW temperature anomalies is from all data prior to 1999 following the method of Polyakov and Timokhov (1994). We assumed that seasonal variations in the AW layer are small and do not affect results of our analysis. 
Linear interpolation was used to interpolate data spatially (for details of spatial interpolation procedure, see Polyakov et al. 2008).

\section{b. Description of models}

The numerical models used here are a 3D coupled ice-ocean model and its $1 \mathrm{D}$ version. The 3D model takes into account ice and ocean dynamics and thermodynamics (Polyakov et al. 1998). The free-surface ocean model employs a 3D Boussinesq, hydrostatic, nonlinear code incorporating a turbulent closure model. The latter follows from the equation of turbulent kinetic energy (TKE) and relates the eddy viscosity $K_{z}$ coefficient, the vertical shear of the horizontal velocity, and the stratification (Kochergin 1987),

$$
K_{z}=l^{2}\left[\left(\frac{\partial U}{\partial z}\right)^{2}+\left(\frac{\partial V}{\partial z}\right)^{2}-\mu \frac{g}{\rho_{o}} \frac{\partial \rho}{\partial z}\right]^{1 / 2}+k_{z b},
$$

where $U$ and $V$ are horizontal velocity components, $\rho$ is water density with $\rho_{o}$ the mean water density, $\mu$ a tunable parameter that is discussed in greater detail below, $g$ is gravitational acceleration, and $k_{z b}=10^{-6} \mathrm{~m}^{2} \mathrm{~s}^{-1}$ is a background vertical viscosity. The parameter $l$ is the turbulence scale, defined as

$$
l^{2}=\alpha \kappa H^{-1} Z_{\zeta} Z_{H} Z_{o}
$$

as was suggested by Voltsinger et al. (1989). In this expression $\alpha=0.55$ (for details, see Kowalik and Polyakov 1999), $\kappa=0.4$ is the von Kármán constant; $Z_{H}=H-z+z_{h}$ and $Z_{\zeta}=z+z_{\zeta}-\zeta$ with $z_{h}$ and $z_{\zeta}(=0.025 \mathrm{~m})$ defining roughness parameters at the bottom $H$ and surface $\zeta$. Here $Z_{H}$ and $Z_{\zeta}$ are used to define two boundary layers, and $Z_{o}=\left(1-1.2 H-2 Z_{H} Z_{\zeta}\right) /\left(H / H_{o}+1\right)$ (Voltsinger et al. 1989); $H_{o}=50 \mathrm{~m}$ is used to apply this expression for $l$ to the deep ocean.

This model is somewhat similar to turbulent closure models based on the Richardson number (e.g., Pacanowski and Philander 1981). When the term under the square root is negative (associated with strong stratification leading to suppressed mixing), the first term in the viscosity expression is put to zero so that $K_{z}=k_{z b}$.

Unlike Kochergin (1987), the present model includes the nondimensional parameter $\mu$ in the model buoyancy term. Tuning of the model to improve model representation was used to define the value of $\mu=0.01$. The following numerical experiments with the model demonstrated satisfactory model performance (e.g., Polyakov and Johnson 2000). For example, in the 1D experiments presented in this paper computed $K_{z}$ values were $(2-4) \times 10^{-6} \mathrm{~m}^{2} \mathrm{~s}^{-1}$ in the ocean interior below the mixed layer where the values of $K_{z}$ were higher by two to three orders of magnitude.

At those times when the stratification is deemed unstable to vertical convection, $K_{z}$ for the vertical segment in question is derived with $\mu=10^{3}$, which leads to rapid homogenization of the density in the layer. In the numerical computations, coefficient of vertical mixing for heat and salt is taken to be 0.1 of $K_{z}$.

Change over time of the model water temperature and salinity profiles is dictated by the surface forcing, the vertical mixing (both diffusive and convective), and the divergences of the advective and horizontal diffusive property fluxes. The numerical model domain spans the Arctic Ocean with Siberian marginal seas and the Barents, Greenland, and Norwegian Seas with a horizontal resolution of $55.56 \mathrm{~km}$ and 29 vertical $z$ levels $(2.5,5,10,15$, $20,25,30,40,50,60,75,100,150,200,250,300,400,500$, $600,750,1000,1500,2000,2500,3000,3500,4000,4500$, and $5000 \mathrm{~m}$ ). Open model boundaries exist between Greenland and Europe and at Bering Strait. The transports at these oceanic open boundaries, river runoff, initial ice thickness, and concentration are prescribed (Polyakov et al. 1998). Note that all of the present analysis focuses on the Eurasian Basin sector of the Arctic where the AW is in close vertical proximity to the surface mixed layer and the base of the sea ice. The thermodynamic coupling between the ice and ocean depends on oceanic heat flux to the ice, which in turn depends on vertical shear and buoyancy in the upper ocean. Atmospheric heat fluxes were computed using daily National Centers for Environmental Prediction (NCEP) reanalysis fields of air temperature, humidity, cloudiness, and wind data separately for cases of open water, thin ice, and thick ice. An increase (decrease) in ice thickness produces a corresponding divergent (convergent) freshwater flux in the upper ocean that, in turn, alters the vertical stratification and the model's ocean vertical diffusivities. The model was initialized at rest with climatological-mean winter ocean temperature and salinity (Polyakov and Timokhov 1994, updated). The daily wind stresses were computed from the NCEP reanalysis sea level pressure (SLP) following Proshutinsky and Johnson (1997). No restoring was used in $3 \mathrm{D}$ model simulations. This $3 \mathrm{D}$ model has been used extensively in the past to simulate aspects of the Arctic Ocean (e.g., Polyakov et al. 1998; Polyakov and Johnson 2000) and marginal seas (e.g., Polyakov and Martin 2000).

The 1D model used here is a column ocean model coupled to a thermodynamic ice model. It was derived from the 3D model by eliminating all horizontal spatial derivatives and the dynamic ice module (the atmospheric stresses were applied directly to the ocean surface). In this 1D model, ocean momentum evolves in time as a 
result of the balance between Coriolis acceleration and vertical stress divergence. One-dimensional column models provide useful insight into the surface mixed layer where the balance of forces is based on relatively simple, physically plausible, observationally well-defined constraints. However, this may be not true for the ocean interior where the internal wave field can have a strong impact on mixing intensity. Observational fine structure and microstructure data suitable for inferring diapycnal eddy diffusivity are scarce in the Arctic, precluding the reliable parameterization of mixing rates for the highlatitude subsurface waters. However, 1D mixing models as a part of more general 3D ocean models have been successfully used to simulate the Arctic Ocean (e.g., Holloway et al. 2007). Frequently in these cases, the turbulence closure models were tuned to improve model representation of observed general features of the Arctic Ocean. A restoring to the model current profile is used to account for the background currents (specifically their shear) not represented in the 1D model. For the Eurasian Basin, mean velocity profiles were derived from modeling experiments (Polyakov and Johnson 2000). For the near-slope area $\left(<84^{\circ} \mathrm{N}\right)$, the observed mean current profile from the Laptev Sea slope current profile was used [Nansen and Amundsen Basin Observational System (NABOS) cruise reports: available online at http://nabos.iarc.uaf.edu/cruise/reports. php]. This profile represents a rather conservative estimate because currents observed there are weak compared with other Eurasian Basin slopes. The 1D model also invoked temperature and salinity restoring below the mixed layer to account for the effects of horizontal advection, which maintains the temperature of the AW core. The one-month restoring constant was multiplied by a factor, which increased gradually from zero at $25 \mathrm{~m}$ to one at $400 \mathrm{~m}$.

The same basic approach was utilized in all (3D and 1D) numerical experiments. Each case examined was run twice, with the second run an exact repeat of the first except for one parameter that was changed. Using this approach, the impact of an anomalous ocean state on the oceanic vertical heat flux was evaluated. For the first run, the 1D model was initialized with observed 2007 temperature and salinity profiles and driven by the atmospheric forcing for that year. The second run used the same forcing, but climatological temperature and salinity data for each analysis location were taken as initial conditions. The same approach based on the 1D model (with climatological atmospheric forcing) was used to investigate the change of oceanic heat fluxes due to stratification changes in the 1970s and 1990s.

Another set of experiments utilized the 3D model to estimate sensitivity of ice thickness to anomalous oceanic heat flux. The 3D model was run for the period 1948-99 forced by the derived atmospheric heat fluxes and wind data. In the second run, the oceanic heat flux to the bottom surface of ice was artificially increased by $0.5 \mathrm{~W} \mathrm{~m}^{-2}$, a value derived from the paired $1 \mathrm{D}$ model experiments. The advantage of this approach compared with hindcast coupled ice-ocean model runs is that it allows direct estimation of the ice thickness change that results from a specified ocean heat flux anomaly $\left(0.5 \mathrm{~W} \mathrm{~m}^{-2}\right)$.

\section{Impacts of $\mathbf{A W}$ warming on high-latitude ice cap \\ a. Change of Arctic Ocean state in recent decades: Observational evidence}

Observations made in 2007 confirmed the large-scale warming of the Eurasian Basin ocean interior started in the early to mid 2000s (Fig. 2). Furthermore, they showed that the warm anomaly had made its way farther eastward, toward the Canadian Basin (Fig. 4). Maximum temperature anomalies of up to $1^{\circ} \mathrm{C}$ can be traced along the AW spreading pathways in the Eurasian and Makarov Basins (Fig. 2) in a pattern similar to that observed in the 1990s (Polyakov et al. 2004, Fig. 2). Point-topoint comparison of Atlantic water temperature from the 1990s and 2007 confirmed the exceptional strength of the recent warming that is, on average, $0.24^{\circ} \mathrm{C}$ greater than the warming in the 1990s. An increase in ocean salinity has accompanied the warming; the basinwide averaged salinity within the 200-800-m layer increased from $34.80 \mathrm{psu}$ in the $1970 \mathrm{~s}$ to $34.84 \mathrm{psu}$ in the $1990 \mathrm{~s}$ (Polyakov et al.2004) and remained at the relatively high salinity of 34.82 psu in 2007. Particularly noticeable warming and salinification were found in the upper AW layer and halocline (100-250 m, Fig. 5), resulting in an increase of density and weakening of stratification. Averaged over the 100-300-m layer, the Brunt-Väisälä frequency (a measure of the static stability of the water column) fell by $12 \%$ from the 1970 s to the 1980 s and by $19 \%$ from the 1980 s to the $1990 \mathrm{~s}$; the total loss of water column stability was about $30 \%$. Continuing this tendency, there was a noticeable loss of water column stability in 2007 compared with climatology, as expressed by negative Brunt-Väisälä frequency anomalies in the upper AWlower halocline (Fig. 6d).

Observations from the 1990s show a shoaling of the AW upper boundary by about $75 \mathrm{~m}$ within the central Makarov Basin relative to climatology (Fig. 7, see also Polyakov et al. 2004). Steele and Boyd (1998) also reported that, in the 1990s, the AW layer within the Amundsen Basin had shoaled by about $40 \mathrm{~m}$ (EWG 1997 climatology used as a reference). Observations 


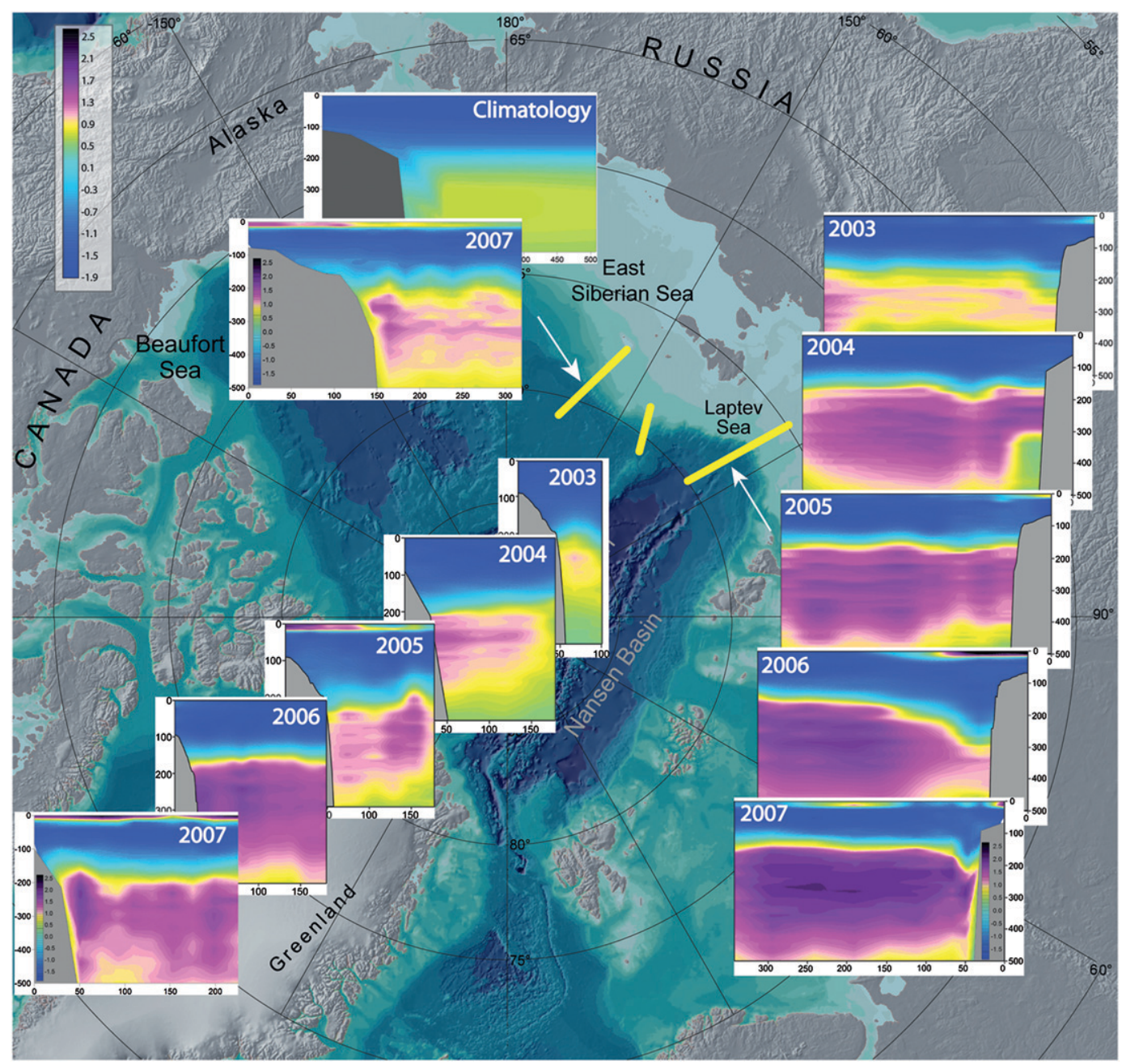

FIG. 4. Vertical cross sections of water temperature $\left({ }^{\circ} \mathrm{C}\right)$ from the Laptev Sea slope (see three series of cascaded plots related to three locations shown by yellow lines on the map). These observations provide evidence of unprecedented warming of the Arctic Ocean.

from 2007 revealed the same domelike spatial structure of roughly the same magnitude $(\sim 90 \mathrm{~m})$ (Fig. 7). Note that for this analysis we took the potential density surface $\sigma_{\theta}=27.40$, which corresponds to $\sim 60-80 \mathrm{~m}$ depth range (Fig. 5). However, the same spatial pattern and magnitude of anomalies are found for other, deeper, isopycnal surfaces including the $\sigma_{\theta}=27.85$ surface (not shown) that typically lies close to the AW core. Similar to the 1990s, the observed shoaling of the AW layer in 2007 has a strong resemblance to the spatial pattern of the 2007 SLP anomalies (not shown, see Ogi et al. 2008), probably due to Ekman pumping.

The extensive 2007 observations provide an excellent opportunity to evaluate the upward spread of AW heat. Ten cross-isobath sections spanning $43^{\circ}-185^{\circ} \mathrm{E}$ (see their locations in Fig. 3) were analyzed (Fig. 8) to quantify the along-slope change of water temperature. The $\Theta-S$ diagram (Fig. 8, left) provides strong evidence that, at low salinities $(<34.3$ psu, i.e., in the halocline and just below the upper mixed layer), temperatures are substantially higher at eastern sections compared with western sections. With the AW layer as the only source of heat, this is strong evidence of the existence of upward heat flux from the AW.

Heat content $Q$ was also used to further quantify the along-slope changes. Using standard notation, heat content $Q\left(\mathrm{~J} \mathrm{~m}^{-2}\right)$ relative to the freezing point is defined as

$$
Q=\int_{z_{1}}^{z_{2}} \rho_{w} c_{p}\left(\Theta-\Theta_{f}\right) d z
$$

where $\Theta$ is potential temperature, $\Theta_{f}$ is the freezing temperature at $0 \mathrm{db}, \rho_{w}$ is water density, $c_{p}$ is specific heat 

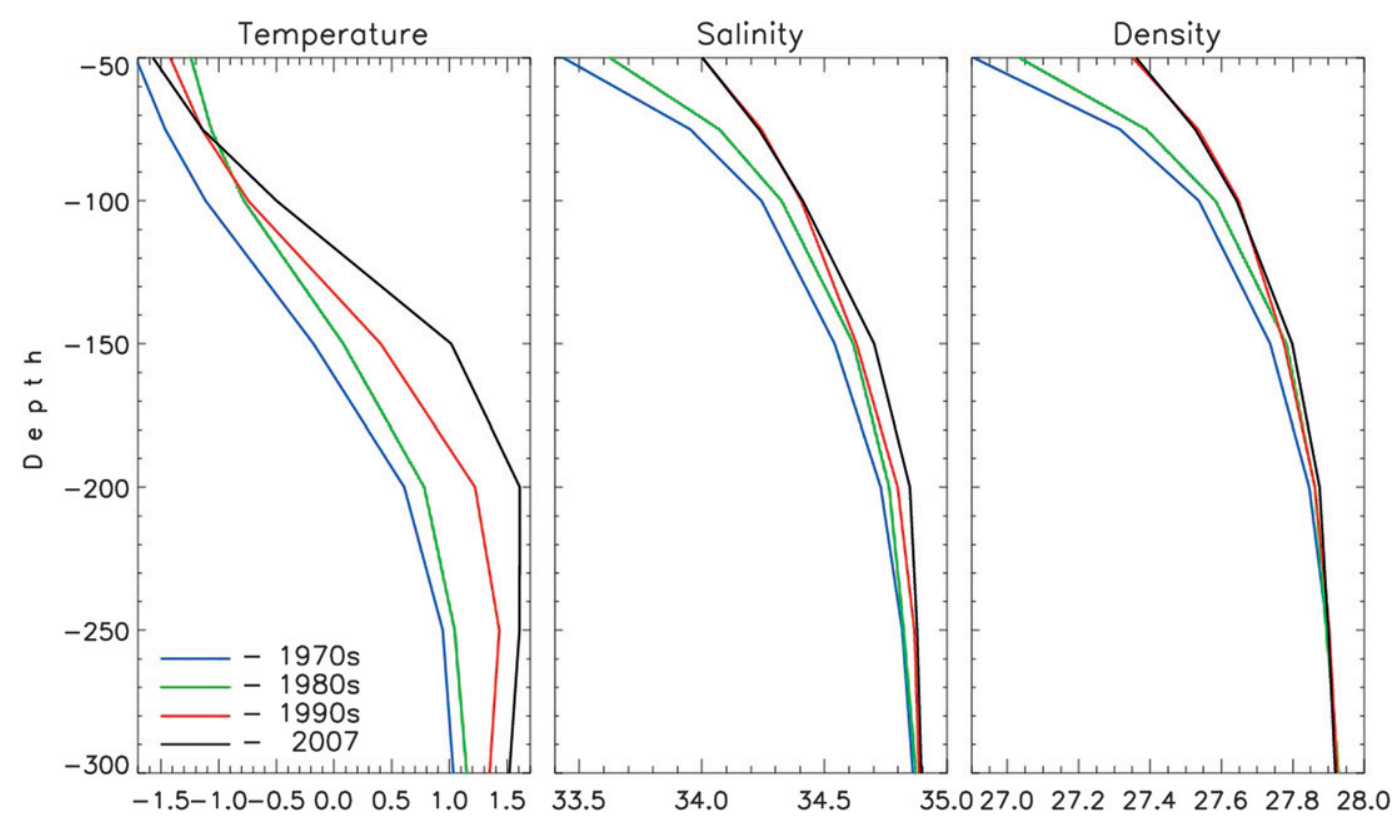

FIG. 5. Vertical profiles of Eurasian Basin water temperature $\left({ }^{\circ} \mathrm{C}\right)$, salinity (psu), and density $\left(\sigma_{q}, \mathrm{~kg} \mathrm{~m}^{-3}\right)$. Vertical axis shows depth in meters. There is a tendency of the upper AW layer and halocline of getting warmer, saltier, and denser in time.

of water, and $z_{1}$ and $z_{2}$ are depths of the upper and lower boundaries. At each section, average $Q$ was derived for two layers: an AW layer and an "overlying" layer (OL). The latter was defined to lie between the shallow temperature minimum and $\Theta=-0.3^{\circ} \mathrm{C}$, which lies close to the upper AW boundary. The depth of the OL upper boundary is $30-50 \mathrm{~m}$ in the Eurasian Basin increasing to $80 \mathrm{~m}$ in the East Siberian Sea, thus avoiding surface waters that are dominated by summer atmospheric heating and the Pacific water intrusions into the Canadian Basin. The AW layer was taken to be between the $0^{\circ} \mathrm{C}$ isotherms with the upper boundary varying from $\sim 80-100 \mathrm{~m}$ in the Eurasian Basin to $220 \mathrm{~m}$ and deeper at the eastern Laptev and East Siberian slopes. At each cross-isobath section, $Q$ in the two layers was estimated for each station, and the resulting values (for each layer on a section) were averaged. The continuous distributions, Fig. 8 (right), were derived with linear interpolation between the average section longitudes.

The along-slope AW and OL $Q$ changes contain some noise due to short-term temperature fluctuations; however, the general tendency is clearly captured by observations. Figure 8 (right) suggests that some heat lost from the AW is gained by the OL along the west to east AW spreading path. This analysis is based on the assumption that the OL in the Eurasian Basin travels in the same direction as the AW core. This assumption is confirmed by mooring-based observations of currents at the continental slope off Svalbard, $\sim 30^{\circ} \mathrm{E}$ (Ivanov et al. 2009); at the Laptev Sea slope, $\sim 125^{\circ} \mathrm{E}$ (Dmitrenko et al. 2008b); and at the junction of the Lomonosov Ridge and the continental slope, $\sim 133^{\circ}-150^{\circ} \mathrm{E}$ (Woodgate et al. 2001).

The derived OL heat gain accounts for up to $7 \%$ of the estimated AW heat loss off Severnaya Zemlya $\left(95^{\circ}-\right.$ $110^{\circ} \mathrm{E}$ ) with much lower estimates elsewhere along the Eurasian slope. The balance of the along-slope decrease in AW $Q$ is presumably vented through the OL to the surface waters, sea ice, or atmosphere and/or spreads laterally beyond the extent of the cross-isobath sections by advection and eddy stirring. The thickness of the OL increases eastward; as a result, a substantial fraction of OL heat gain remains within the halocline and does not reach the surface (Rudels et al. 1996; Walsh et al. 2007). However, Figs. 6a,b provide evidence that AW heat warms even the uppermost layers (just beneath the upper mixed layer). For example, temperatures from the Laptev $\left(125^{\circ}\right.$ and $\left.142^{\circ} \mathrm{E}\right)$ and East Siberian $\left(159^{\circ}\right.$ and $\left.185^{\circ} \mathrm{E}\right)$ Seas sections were $0.1^{\circ}-0.3^{\circ} \mathrm{C}$ higher at $50-75 \mathrm{~m}$ than western section temperatures (longitudes $<110^{\circ} \mathrm{E}$ ). This analysis relies on the knowledge of AW pathways. These pathways are well established for along-slope boundary currents but unfortunately are not as reliable for the ocean interior. As a result, this approach cannot be easily implemented for the central basin. However, our analysis offers important observation-based clues that indicate an upward spread of AW heat in the Arctic Ocean. 


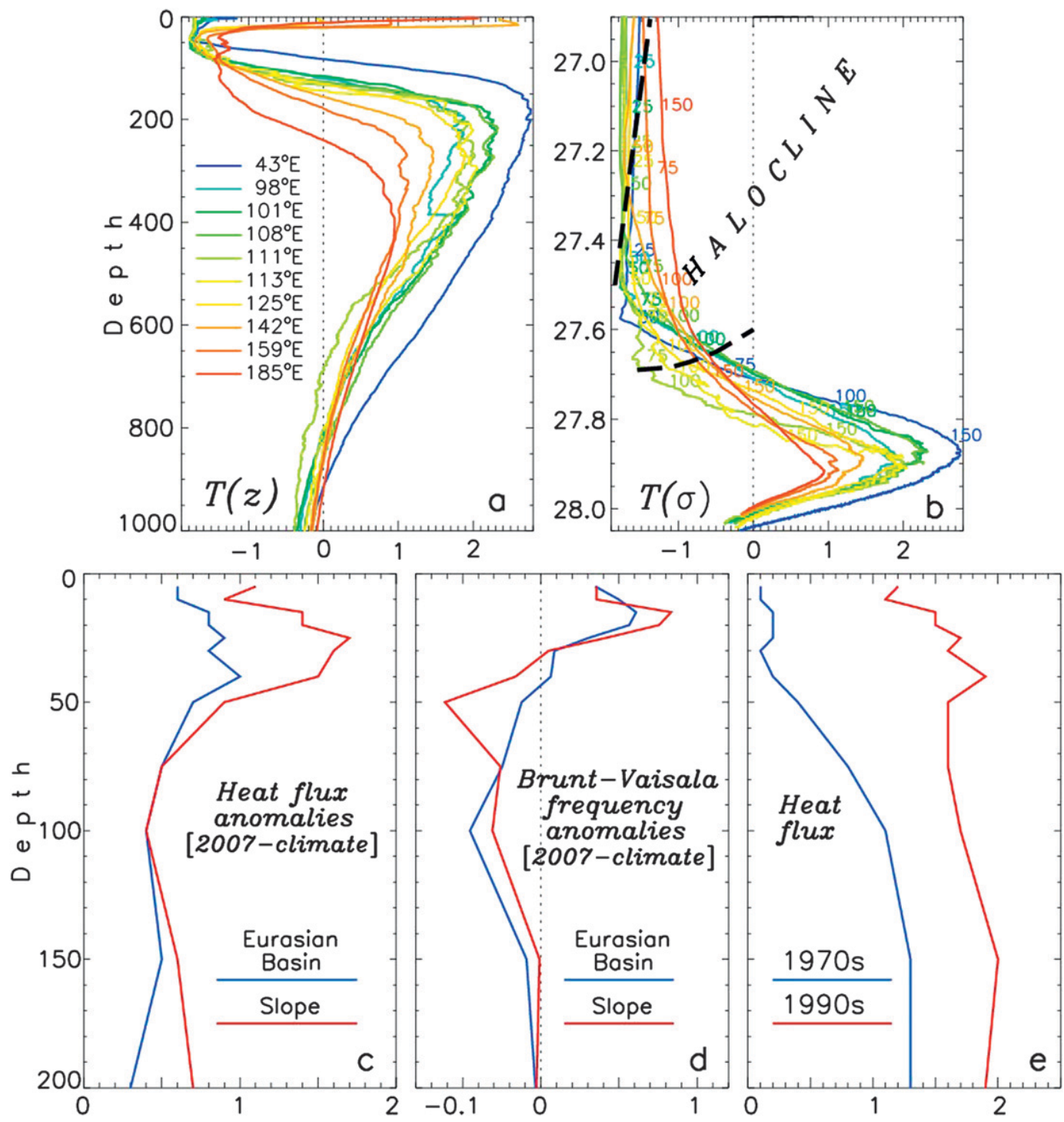

FIG. 6. (a) Temperature $T(z)\left({ }^{\circ} \mathrm{C}\right)$ profiles averaged over 10 cross sections crossing the Siberian continental slope shown in Fig. 3; same profiles but for $T(\sigma)$ (vertical axis is density instead of depth). Black dashed lines show approximate position of halocline; colored numbers show depth $(\mathrm{m})$ for each profile. (c) Simulated upward annualmean heat flux anomalies (2007 vs climatology, $\mathrm{W} \mathrm{m}^{-2}$ ) due to AW heat content change. (d) The Brunt-Väisälä frequency anomalies (2007 vs climatology, $1000 \mathrm{~s}^{-2}$ ) derived from temperature and salinity profiles. Note different horizontal scales for positive and negative values. (e) Simulated upward decadal-mean heat flux $\left(\mathrm{W} \mathrm{m} \mathrm{m}^{-2}\right)$ in the Eurasian Basin. Vertical axes show depth (m).

\section{b. Impacts of $A W$ warming on Arctic ice: Model experiments}

Oceanographic observations documenting the significant warming (by $\sim 1^{\circ} \mathrm{C}$ ) accompanied by weaker ocean stratification suggest that the upward AW heat flux may have increased recently and contributed to the sea ice decline in the Eurasian Basin. There is, however, no direct observation-based evidence for such a link. We therefore used numerical modeling (1D and $3 \mathrm{D}$ ) to investigate changes in the rate of upward AW heat transfer and its potential impact on the sea ice cover.

Using the 1D model, oceanic heat fluxes for the 1970s and 1990s averaged over the Eurasian Basin were estimated (Fig. 6e). For the first experiment, the 1D model was initialized with temperature and salinity profiles from the 1970s. The second experiment used temperature and salinity data from the 1990s. Simulated heat fluxes averaged over the Eurasian Basin are presented in Fig. 6e. The model results suggest that change of stratification 

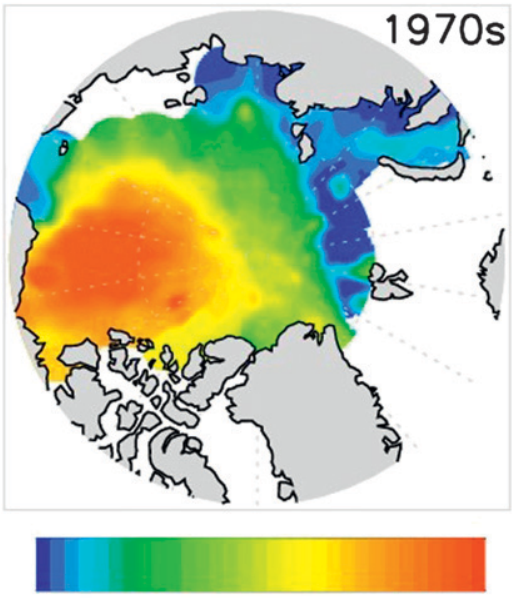

0

250
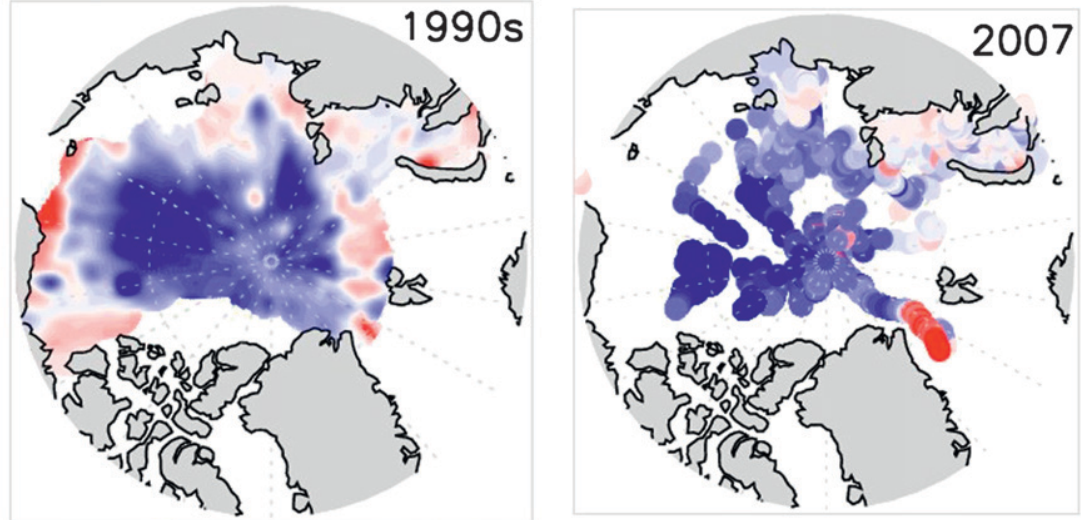

$-90$

0

90

FIG. 7. Spatial distribution of (left) the Arctic Ocean upper layer thickness (m) in the 1970s and layer thickness anomalies (m) for (middle) the 1990s and (right) 2007 relative to the 1970s. The layer is defined by the potential density $\sigma_{\theta}=27.40$ surface. For anomalies, the blue color identifies regions where the surface was elevated (i.e., the upper layer was thinner).

alone caused an increase in the upward ocean heat flux $F_{w}$ of $0.5-1.0 \mathrm{~W} \mathrm{~m}^{-2}$ in the $1990 \mathrm{~s}$ relative to the $1970 \mathrm{~s}$. Other factors might have further influenced $F_{w}$; however, additional 1D model experiments showed that changes in the atmospheric forcing had negligible effects on $F_{w}$.

The 1D model study was subsequently extended to 2007, and vertical heat flux anomalies (versus climatology) of comparable magnitude to those inferred for the 1990s were obtained: $F_{w}^{\prime} \approx 0.5 \mathrm{~W} \mathrm{~m}^{-2}$ or more (cf. anomalies shown in Figs. 6c,e; in Fig. 6e anomalies are defined by the distances between the red and blue profiles). As for the $1990 \mathrm{~s}$, weaker oceanic stratification in the $\sim 50-150 \mathrm{~m}$ depth interval in 2007, compared with climatology, (Fig. 6d) resulted in greater vertical transfer of AW heat in the model. (This additional heat flux provides a possible explanation for the observed OL warming deduced from the 2007 temperature observations, Figs. 6a,b.) From $\sim 50 \mathrm{~m}$ depth, wind-driven mixing effectively transferred this anomalous heat to the surface (Fig. 6c), even though the stratification in the upper 50-m layer in the Eurasian
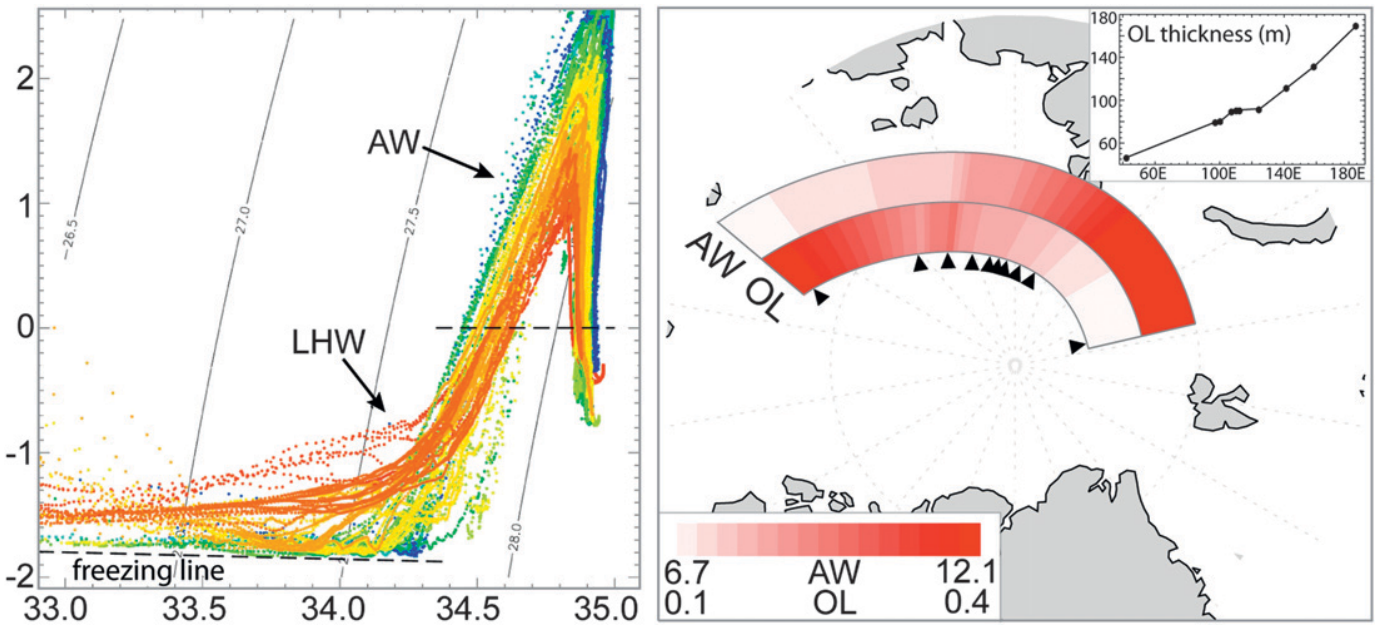

FIG. 8. (left) Potential temperature-salinity plot for the 10 cross sections carried out in 2007 . All temperature $\left({ }^{\circ} \mathrm{C}\right)$ and salinity (psu) profiles for each cross section are shown. Color notation is explained in Fig. 6a. At low salinities $(<34.3 \mathrm{psu})$, temperatures are substantially higher at eastern sections (orange) compared with western sections (green). Water masses shown are lower-halocline water (LHW) and Atlantic water (AW). (right) Anomalous heat content $\left(\mathrm{GJ} \mathrm{m}^{-2}\right)$ in the AW and overlying $(\mathrm{OL})$ layers. Black triangles show positions of cross sections that provided observational data; linear interpolation is used in between. Insert shows along-slope OL thickness change. Both panels provide evidence of the upward spread of AW heat along the AW path in the basin interior. 


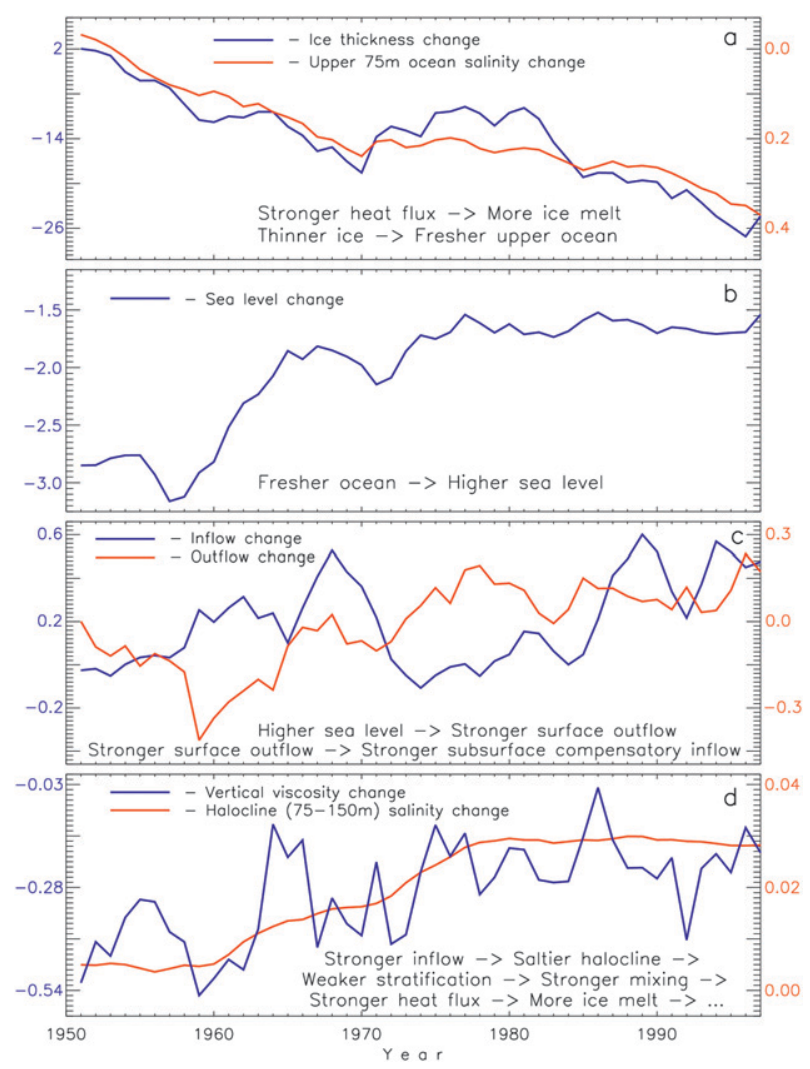

FIG. 9. Time series of simulated differences of Eurasian Basin (a) ice thickness $(\mathrm{cm})$ and salinity (psu) in the upper 75-m ocean layer, (b) sea level $(\mathrm{cm}),(\mathrm{c})$ water outflow in the upper $75 \mathrm{~m}$ and inflow in

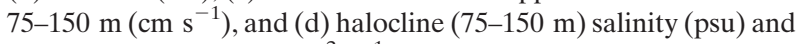
upper $150-\mathrm{m}$ viscosity $\left(\mathrm{cm}^{2} \mathrm{~s}^{-1}\right)$ between two model runs (in the second run, the oceanic heat flux to the bottom of ice was increased by $0.5 \mathrm{~W} \mathrm{~m}^{-2}$ ).

Basin was stronger in 2007 than climatology. This upward heat transfer was enhanced by anomalously strong winds observed in the Siberian sector of the Arctic Ocean in 2007 (Stroeve et al. 2008).

To investigate the possible effects of this anomalous vertical heat flux on the sea ice thickness over recent decades, the 3D model was employed. Comparing the reference model run to one with an additional $0.5 \mathrm{~W} \mathrm{~m}^{-2}$ ocean heat flux, we found an $\sim 0.28 \mathrm{~m}$ decrease in simulated Eurasian Basin ice thickness after five decades of integration (Fig. 9). Figure 9 demonstrates that increased oceanic heat flux not only affects ice thickness but also engages important positive feedback mechanisms with salinity, providing long-term system memory. Suppressed ice production induced by stronger oceanic heat flux to the bottom of ice governs increasing freshening of the upper 75-m ocean layer (Fig. 9a). The model further suggests that this freshening leads to elevated sea level (Fig. 9b) with a maximum in the central ocean north of Greenland (the spatial pattern is not shown) leading to enhanced outflow of surface waters from the Eurasian Basin into the Greenland Sea (Fig. 9c). At greater depth (75-150 $\mathrm{m})$, currents and salinity vary in response to the anomalous oceanic heat flux but in the opposite sense of the upper ocean. We found that the outflow of the surface waters from the Eurasian Basin results in enhanced compensatory inflow of salty water from the Greenland Sea (Fig. 9c) and salinification of the halocline and upper AW layer (Fig. 9d). An increase of salinity over the AW layer weakened stratification and enhanced mixing (Fig. 9d) and upward AW heat flux. In the experiment with increased oceanic heat flux to the bottom of ice (which resulted in thinner ice), the Brunt-Väisälä frequency in the $75-150-m$ layer was decreased by $18 \%$ from the 1970 s to the 1980 s and by $12 \%$ from the 1980 s to the 1990 s; the total loss of water column stability was about $30 \%$. This relationship suggested by the model represents a positive feedback mechanism through which increased halocline salinity in the upper AW layer acts to decrease ice thickness through enhancement of upward AW heat flux resulting in additional inflow of dense water from the Norwegian Sea and further salinification of the halocline and upper AW of the Eurasian Basin. This explains why a simple formula relating ice thickness change to anomalous oceanic heat flux $F_{w}^{\prime}$ with the heat of fusion of ice as a factor (and, owing to its simplicity, ignoring this positive feedback) produces lower estimates of ice thickness decay corresponding to $F_{w}^{\prime} \approx 0.5 \mathrm{~W} \mathrm{~m}^{-2}$. Sensitivity of simulated ice thickness to $F_{w}^{\prime}$ from Steele and Flato's (2000) review is somewhat higher, up to $0.35 \mathrm{~m}$ per $0.5 \mathrm{~W} \mathrm{~m}^{-2}$. Thus, $0.28-0.35 \mathrm{~m}$ may be considered as a measure of ice thickness change due to anomalous oceanic heat flux $F_{w}^{\prime} \approx 0.5 \mathrm{~W} \mathrm{~m}^{-2}$. This estimate represents a significant fraction of the $\sim 1 \mathrm{~m}$ total ice thickness loss between the period prior to the 1970s and the 1990s derived from submarine-based observations (Rothrock et al. 2003).

\section{c. Role of various factors in long-term change of the Arctic ice cap}

To put our estimates of ice thickness loss due to AW heat in greater context, we examined observations of seasonal fast-ice thickness (motionless one-year sea ice anchored to the sea floor and/or the shore, which melts and reforms each year). Fast-ice thickness in late winter provides an annual measure of ice growth due to "pure" atmospheric thermodynamic forcing. (This is true for the vast and shallow Siberian shelves where there is negligible deep ocean influence on the local sea ice, but may not hold for the narrow Alaskan and Canadian shelves.) Fastice thickness records from 15 locations along the Siberian coast are available (see the map with these locations in Fig. 1 from Polyakov et al. 2008). A composite time series of fast-ice thickness obtained by averaging these 15 
records was used to derive an average rate of ice thickness loss of $0.33 \mathrm{~cm} \mathrm{yr}^{-1}$ since 1965 (defined by linear trend). This equates to an 11.6- $\mathrm{cm}$ difference in fast-ice thickness between the mid 1960s and early 2000s. Since Siberian fast ice is, by definition (with very few exceptions), oneyear ice, a 0.116-m ice-thickness difference implies that, on average, during each year in the mid 1960s fast ice was thicker by $\sim 0.116 \mathrm{~m}$ than in the early $2000 \mathrm{~s}$. An average (1985-2006) lifetime over which an ice floe of pack ice inhabited the Eurasian Basin was $\sim 1.9 \mathrm{yr}$ (N. Platonov 2009, personal communication). Thus, the impact of atmospheric thermodynamic forcing on the Eurasian Basin pack ice would have resulted in an ice thickness loss of $0.116 \mathrm{~m} \mathrm{yr}^{-1} \times 1.9 \mathrm{yr}=0.22 \mathrm{~m}$ (assuming that fast ice and drifting ice exhibit the same rate of decline). This estimate extends over the winter (September-May) season only, when fast ice exists. Assuming the same rate of atmospheric impact in the summer [cf. 1979-2008 annual (summer) trends of Arctic surface air temperature of $0.64^{\circ} \mathrm{C}\left(0.44^{\circ} \mathrm{C}\right)$ per decade, Bekryaev et al. (2010)] yields $\sim 0.29 \mathrm{~m}$ of ice thickness loss due to atmospheric thermodynamic forcing. This compares well with modeling estimates of $\sim 0.28-0.35 \mathrm{~m}$ ice thickness loss due to anomalous AW heat flux. We note, however, that our estimate of the impact of atmospheric thermodynamic forcing should be viewed as conservative because it neglects the effects of upper-ocean solar heating through leads and consequent ice bottom melting. Thus, we conclude that in the eastern Arctic, over several recent decades, added ice-bottom melting due to AW heat flux was comparable to the added surface melting due to atmospheric thermodynamic forcing. We speculate that the remaining ice thickness loss was presumably due to a change of mechanical forcing such as dynamically driven redistribution of ice in the basins and advection of ice out of the Arctic Ocean.

\section{Conclusions}

Analysis of historical and modern observational data demonstrates that the temperature of intermediate-depth Arctic Ocean AW has increased dramatically in recent decades. The current warming culminated in 2007 when AW temperatures were, on average, $0.24^{\circ} \mathrm{C}$ warmer than those seen during the previous AW warming event in the 1990s. The maximum temperature anomalies of up to $1^{\circ} \mathrm{C}$ were observed in the Eurasian and Makarov Basins. The AW warming has been associated with a shoaling of the upper AW boundary and weakening of the Eurasian Basin stratification since the late 1970s. These changes in ocean stratification are consistent with the large-scale increase of atmospheric cyclonicity, which led to enhanced ice production and sustained draining of freshwater from the Arctic Ocean in response to winds (e.g., Steele and
Boyd 1998; Johnson and Polyakov 2001; Polyakov et al. 2008).

Available observations suggest upward AW heat transport through the Eurasian Basin halocline along its spreading pathway. Modeling (1D) experiments suggest that changes in the Arctic Ocean state resulted in an increase in vertical ocean heat flux of $0.5 \mathrm{~W} \mathrm{~m}^{-2}$. Threedimensional coupled ice-ocean model experiments predicted a $28-35-\mathrm{cm}$ thinning of the sea ice cover over $\sim 50$ years of integration in response to this anomalous ocean heat flux. Our modeling experiments demonstrate a possible positive feedback mechanism through which extra freshwater from ice melt leads to extra outflow from the upper Arctic Ocean with a compensating inflow of denser waters of halocline and upper AW layer. This increased lower-layer salinity acts to decrease ice thickness through enhanced upward AW heat flux, resulting in further salinification of this oceanic layer of the Eurasian Basin. The observed warming of the Pacific waters may have a similar effect on ice on the Canadian side of the Arctic (not specifically considered in this paper; for discussion see, e.g., Shimada et al. 2006). The anomalous upward heat loss from the AW to the sea ice, $0.5 \mathrm{~W} \mathrm{~m}^{-2}$, constitutes a significant addition to the average upward heat flux (prior estimates for the middle of the twentieth century range between 1 and $4 \mathrm{~W} \mathrm{~m}^{-2}$ ). Still, this oceanic heat loss, because it takes place in a limited region, is not large enough to counteract the ocean warming that has been taking place the last few decades. Domingues et al. (2009, manuscript submitted to Geophys. Res. Lett.) estimate the global upper-ocean heat uptake to be $16 \pm 3 \times$ $10^{22} \mathrm{~J}$ (equivalent to $0.36 \mathrm{~W} \mathrm{~m}^{-2}$ ) from 1961 to 2003 . There is, therefore, little reason to expect that the preconditioning effect of Arctic AW on the polar ice cap will subside in the near term, although there may be shortterm periods (decadal scale and shorter) during which the AW cools. The bottom ice loss of 0.24-0.35 m compares to $0.29 \mathrm{~m}$ of ice thickness loss due to atmospheric thermodynamic forcing estimated from fast-ice thickness decline. Both factors were likely important to the estimated 1-m decay of central-basin sea ice reported by Rothrock et al. (2003). We conclude that AW warming helped precondition the polar ice cap for the extreme losses of recent years.

The present results depend crucially on the turbulence closure scheme employed by the ocean models. That scheme returns climatological vertical diffusivity values for the stratified waters below the surface mixed layer in the range of (3-5) $\times 10^{-5} \mathrm{~m}^{2} \mathrm{~s}^{-1}$. For reference, instability of the background internal wave field in the midlatitude ocean interior supports a diapycnal diffusivity $O\left(10^{-5} \mathrm{~m}^{2} \mathrm{~s}^{-1}\right)$ (Gregg 1987). A similar 1D ice-ocean modeling study, discussed by Toole et al. (2010), that 
invokes no additional mixing beyond that driven by shear instability of resolved ocean flows finds no influence on the surface mixed layer or sea ice cover by subsurface ocean heat deeper than about $5 \mathrm{~m}$ below the mixed layer base in the central Canadian Basin. Theoretical considerations supported by fine structure and microstructure observations suggest that the effective diapycnal diffusivity depends on the energy density of the wave field (Henyey et al. 1986; Gregg 1989; Polzin et al. 1995). Moreover, unlike the current model's turbulence closure scheme, the midlatitude studies indicate that, for the same buoyancy-scaled internal wave energy density, the diapycnal diffusivity resulting from wave breaking is independent of the density stratification.

In comparison to midlatitudes, the Arctic Ocean internal wave field is weak; the few available microstructure observations suggest very small diffusivities, $\sim 10^{-5} \mathrm{~m}^{2} \mathrm{~s}^{-1}$ and less in the Arctic Ocean interior (e.g., Rainville and Winsor 2008; Fer 2009). Resulting turbulent heat fluxes from the AW layer are also weak, $<1 \mathrm{~W} \mathrm{~m}^{-2}$. However, there is a wide spread of flux magnitudes depending on geographical location. For example, Padman and Dillon (1987) estimated heat fluxes above the AW core (320$430 \mathrm{~m}$ ) using microstructure profiles from the Beaufort Sea to be in the range $0.02-0.1 \mathrm{~W} \mathrm{~m}^{-2}$. Heat fluxes in the Canada Basin at the base of the mixed layer and below ice were estimated as $0.3-1.2$ and $0.2 \mathrm{~W} \mathrm{~m}^{-2}$; over the Chukchi Borderlands the estimates were higher, 2.1-3.7 and $3.5 \mathrm{~W} \mathrm{~m}^{-2}$ (Shaw et al. 2009). Padman and Dillon (1991) analyzed microstructure profiles from the vicinity of the Yermak Plateau and found vertical eddy diffusivity of $\sim 2.5 \times 10^{-4} \mathrm{~m}^{2} \mathrm{~s}^{-1}$ in the pycnocline, implying an upward heat flux of $25 \mathrm{~W} \mathrm{~m}^{-2}$. Recently, Sirevaag and Fer (2009), using observations from north of Svalbard, found heat fluxes of $O\left(100 \mathrm{~W} \mathrm{~m}^{-2}\right)$ at the ice-ocean interface within the branches of the West Spitsbergen Current, emphasizing the importance of mixing along the deep basin margins. Concurrent measurements of turbulent dissipation and temperature-salinity finestructure suggested double-diffusive heat fluxes of $\sim 1 \mathrm{~W} \mathrm{~m}^{-2}$ along the eastern Eurasian Basin's boundaries and in marginal seas (Lenn et al. 2009), consistent with previous estimates of enhanced turbulent (Padman 1995) and tidal (Polyakov 1995; Holloway and Proshutinsky 2007) mixing along the boundaries. The simulated heat loss from the AW layer (1-2 $\mathrm{W} \mathrm{m}^{-2}$ for the 1970-90s, enhanced recently by $\sim 0.5 \mathrm{~W} \mathrm{~m}^{-2}$ ) is somewhat stronger than the observational estimates of Lenn et al. (2009). Given the highly intermittent nature of turbulent mixing events and the wide range of observed magnitudes, extensive turbulence measurements are needed to pin diffusivity down to within a factor of 2 or 3 . Furthermore, mesoscale eddies inhabiting the continental margins of the Eurasian Basin
(Woodgate et al. 2001; Dmitrenko et al. 2008a) may provide an effective means for upward heat transport from the AW to the base of the upper mixed layer. The eddyinduced vertical circulation can cause the intermediate waters to shoal to depths where it can be mixed with upper-ocean waters by wind-driven turbulence (Pollard and Regier 1992). Clearly, the magnitude of the eddyinduced effective diffusivity remains to be determined.

The present observational analysis documents clear evidence of AW layer warming and the upward spread of AW heat to the base of the upper mixed layer. The modeling results are consistent with the observations showing upward heat transport from the AW layer. However, owing to model limitations, we place less confidence on the modeled rates of warming. Understanding the key factors influencing the upward transfer of deep-ocean heat to the surface mixed layer and sea ice base remains a central research question. Addressing it is critical for developing reliable forecasts of the future state of the Arctic ice cap.

Acknowledgments. This study was supported by JAMSTEC (IP and VI), NOAA (IP, VI, and ID), NSF (IP, VA, VI, ID, JT, and MS), NASA (IP and VI), BMBF (ID), and UK NERC (SB) grants. We thank J. Moss for help with the graphics and U. Bhatt, U. Schauer, B. Rudels, and J. Walsh for insightful comments. The findings presented in this paper are of the authors and not NSF/NOAA.

\section{REFERENCES}

Bekryaev, R. V., I. V. Polyakov, and V. A. Alexeev, 2010: Role of polar amplification in long-term surface air temperature variations and modern arctic warming. J. Climate, 23, 3888-3906.

Boyd, T. J., M. Steele, R. D. Muench, and J. T. Gunn, 2002: Partial recovery of the Arctic Ocean halocline. Geophys. Res. Lett., 29, 1657, doi:10.1029/2001GL014047.

Carmack, E. C., R. W. Macdonald, R. G. Perkin, F. A. McLaughlin, and R. J. Pearson, 1995: Evidence for warming of Atlantic Water in the southern Canadian Basin of the Arctic Ocean: Results from the Larsen-93 expedition. Geophys. Res. Lett., 22, 1061-1064.

Comiso, J. C., C. L. Parkinson, R. Gersten, and L. Stock, 2008: Accelerated decline in the Arctic sea ice cover. Geophys. Res. Lett., 35, L01703, doi:10.1029/2007GL031972.

Dmitrenko, I. A., S. A. Kirillov, V. V. Ivanov, and R. A. Woodgate, 2008a: Mesoscale Atlantic water eddy off the Laptev Sea continental slope carries the signature of upstream interaction. J. Geophys. Res., 113, C07005, doi:10.1029/2007JC004491.

_ , and Coauthors, 2008b: Toward a warmer Arctic Ocean: Spreading of the early 21st century Atlantic Water warm anomaly along the Eurasian Basin margins. J. Geophys. Res., 113, C05023, doi:10.1029/2007JC004158.

EWG, 1997: Joint U.S.-Russian atlas of the Arctic Ocean. National Snow and Ice Data Center Environmental Working Group, CD-ROM. 
Fer, I., 2009: Weak vertical diffusion allows maintenance of cold halocline in the central Arctic. Atmos. Oceanic Sci. Lett., 2 (3), 148-152.

Gregg, M. C., 1987: Diapycnal mixing in the thermocline: A review. J. Geophys. Res., 92, 5249-5286.

_- 1989: Scaling turbulent dissipation in the thermocline. J. Geophys. Res., 94, 9686-9698.

Henyey, F. S., J. Wright, and S. M. Flatté, 1986: Energy and action flow through the internal wave field: An Eikonal approach. J. Geophys. Res., 91 (C7), 8487-8495.

Holloway, G., and A. Proshutinsky, 2007: Role of tides in Arctic ocean/ice climate. J. Geophys. Res., 112, C04S06, doi:10.1029/ 2006JC003643.

- , and Coauthors, 2007: Water properties and circulation in Arctic Ocean models. J. Geophys. Res., 112, C04S03, doi:10.1029/ 2006JC003642.

Ivanov, V. V., and Coauthors, 2009: Seasonal oceanic variability off Svalbard in 2004-06. Deep-Sea Res. I, 56, 1-14.

Johnson, M. A., and I. V. Polyakov, 2001: The Laptev Sea as a source for recent Arctic Ocean salinity changes. Geophys. Res. Lett., 28, 2017-2020.

Kochergin, V. P., 1987: Three-dimensional prognostic models. Three Dimensional Coastal Ocean Models, N. H. Heaps, Ed., Amer. Geophys. Union, 201-208.

Kowalik, Z., and I. Polyakov, 1999: Diurnal tides over Kashevarov Bank, Okhotsk Sea. J. Geophys. Res., 104 (C3), 5361-5380.

Krishfield, R. A., and D. K. Perovich, 2005: Spatial and tempora variability of oceanic heat flux to the Arctic ice pack. J. Geophys. Res., 110, C07021, doi:10.1029/2004JC002293.

Lenn, Y. D., and Coauthors, 2009: Vertical mixing at intermediate depths in the Arctic boundary current. Geophys. Res. Lett., 36, L05601, doi:10.1029/2008GL036792.

Martinson, D. G., and M. Steele, 2001: Future of the Arctic Sea ice cover: Implications of an Antarctic analog. Geophys. Res. Lett., 28, 307-310.

Meier, W. N., J. Stroeve, and F. Fetterer, 2007: Whither Arctic sea ice? A clear signal of decline regionally, seasonally and extending beyond the satellite record. Ann. Glaciol., 46, 428-434.

Morison, J., M. Steele, and R. Andersen, 1998: Hydrography of the upper Arctic Ocean measured from the nuclear submarine U.S.S. Pargo. Deep-Sea Res. I, 45, 15-38.

Nghiem, S. V., I. G. Rigor, D. K. Perovich, P. Clemente-Colón, J. W. Weatherly, and G. Neumann, 2007: Rapid reduction of Arctic perennial sea ice. Geophys. Res. Lett., 34, L19504, doi:10.1029/2007GL031138.

Ogi, M., I. G. Rigor, M. G. McPhee, and J. M. Wallace, 2008: Summer retreat of Arctic sea ice: Role of summer winds. Geophys. Res. Lett., 35, L24701, doi:10.1029/2008GL035672.

Pacanowski, R. C., and S. G. H. Philander, 1981: Parameterization of vertical mixing in numerical models of tropical oceans. J. Phys. Oceanogr., 11, 1443-1451.

Padman, L., 1995: Small-scale physical processes in the Arctic Ocean. Arctic Oceanography: Marginal Ice Zones and Continental Shelves, Geophys. Monogr., Vol. 49, Amer. Geophys. Union, 97-129.

— Beaufort Sea thermohaline staircase. J. Geophys. Res., 92 (C10), 10 799-10 806.

— during the Coordinated Eastern Arctic Experiment. J. Geophys. Res., 96 (C3), 4769-4782.

Parkinson, C. L., D. J. Cavalieri, P. Gloersen, H. J. Zwally, and J. C. Comiso, 1999: Arctic sea ice extents, areas, and trends, 1978-1996. J. Geophys. Res., 104, 20 837-20 856.
Perovich, D. K., J. A. Richter-Menge, K. F. Jones, and B. Light, 2008: Sunlight, water, and ice: Extreme Arctic sea ice melt during the summer of 2007. Geophys. Res. Lett., 35, L11501, doi:10.1029/2008GL034007.

Pollard, R. T., and L. A. Regier, 1992: Vorticity and vertical circulation at an ocean front. J. Phys. Oceanogr., 22, 609-625.

Polyakov, I. V., 1995: Maintenance of the Arctic Ocean largescale baroclinic structure by the M2 tide. Polar Res., 13, 219232.

— , and L. A. Timokhov, 1994: Mean fields of temperature and salinity of the Arctic Ocean. Russ. Meteor. Hydrol., 7, 33-38. , and M. Johnson, 2000: Arctic decadal and interdecadal variability. Geophys. Res. Lett., 27, 4097-4100.

_ and S. Martin, 2000: Interaction of the Okhotsk Sea diurnal tides with the Kashevarov Bank polynya. J. Geophys. Res., 105 (C2), 3281-3294.

_ I. Y. Kulakov, S. A. Kolesov, N. E. Dmitriev, R. S. Pritchard, D. Driver, and A. K. Naumov, 1998: Coupled sea ice-ocean model of the Arctic Ocean. J. Offshore Mech. Arctic Eng., 120, $77-84$.

, and Coauthors, 2004: Variability of the intermediate Atlantic Water of the Arctic Ocean over the last 100 years. J. Climate, 17, 4485-4497.

_ and Coauthors, 2005: One more step toward a warmer Arctic. Geophys. Res. Lett., 32, L17605, doi:10.1029/2005GL023740.

and Coauthors, 2008: Arctic Ocean freshwater changes over the past 100 years and their causes. J. Climate, 21, 364-384.

Polzin, K. L., J. M. Toole, and R. W. Schmitt, 1995: Finescale parameterizations of turbulent dissipation. J. Phys. Oceanogr., 25, 306-328.

Proshutinsky, A., and M. Johnson, 1997: Two circulation regimes of the wind-driven Arctic Ocean. J. Geophys. Res., 102 (C6), 12 493-12 514.

Quadfasel, D. A., A. Sy, D. Wells, and A. Tunik, 1991: Warming in the Arctic. Nature, 350, 385.

Rainville, L., and P. Winsor, 2008: Mixing across the Arctic Ocean: Microstructure observations during the Beringia 2005 Expedition. Geophys. Res. Lett., 35, L08606, doi:10.1029/2008GL033532.

Rothrock, D. A., J. Zhang, and Y. Yu, 2003: The Arctic ice thickness anomaly of the 1990s: A consistent view from observations and models. J. Geophys. Res., 108, 3083, doi:10.1029/2001JC001208.

Rudels, B., E. P. Jones, L. G. Anderson, and G. Kattner, 1994: On the intermediate depth waters of the Arctic Ocean. The Polar Oceans and Their Role in Shaping the Global Environment: The Nansen Centennial Volume, Geophys. Monogr., Vol. 85, Amer. Geophys. Union, 33-46.

L. G. Anderson, and E. P. Jones, 1996: Formation and evolution of the surface mixed layer and halocline of the Arctic Ocean. J. Geophys. Res., 101, 8807-8821.

Shaw, W. J., T. P. Stanton, M. G. McPhee, J. H. Morison, and D. G. Martinson, 2009: Role of the upper ocean in the energy budget of Arctic sea ice during SHEBA. J. Geophys. Res., 114, C06012, doi:10.1029/2008JC004991.

Shimada, K., F. McLaughlin, E. Carmack, A. Proshutinsky, S. Nishino, and M. Itoh, 2004: Penetration of the 1990s warm temperature anomaly of Atlantic Water in the Canada Basin. Geophys. Res. Lett., 31, L20301, doi:10.1029/2004GL02086.

, T. Kamoshida, M. Itoh, S. Nishino, E. Carmack, F. McLaughlin, S. Zimmermann, and A. Proshutinsky, 2006: Pacific Ocean inflow: Influence on catastrophic reduction of sea ice cover in the Arctic Ocean. Geophys. Res. Lett., 33, L08605, doi:10.1029/ 2005GL025624. 
Sirevaag, A., and I. Fer, 2009: Early spring oceanic heat fluxes and mixing observed from drift stations north of Svalbard. J. Phys. Oceanogr., 39, 3049-3069.

Steele, M., and T. Boyd, 1998: Retreat of the cold halocline layer in the Arctic Ocean. J. Geophys. Res., 103, 10 419-10 435.

—, and G. Flato, 2000: Sea ice growth, melt, and modeling: A survey. The Freshwater Budget of the Arctic Ocean, E. L. Lewis and E. P. Jones, Eds., Kluwer, 549-587.

Stroeve, J., M. Serreze, S. Drobot, S. Gearheard, M. Holland, J. Maslanik, W. Meier, and T. Scambos, 2008: Arctic sea ice extent plummets in 2007. Eos, Trans. Amer. Geophys. Union, 89, 13-14.

Swift, J. H., E. P. Jones, K. Aagaard, E. C. Carmack, M. Hingston, R. W. MacDonald, F. A. McLaughlin, and R. G. Perkin, 1997: Waters of the Makarov and Canada basins. Deep-Sea Res., 44, 1503-1529.

Toole, J. M., M.-L. Timmermans, D. K. Perovich, R. A. Krishfield, A. Proshutinsky, and J. A. Richter-Menge, 2010: Influences of the ocean surface mixed layer and thermohaline stratification on arctic sea ice in the central Canada Basin. J. Geophys. Res., 115, C10018, doi:10.1029/2009JC005660.

Voltsinger, N. E., K. A. Klevanny, and E. N. Pelinovsky, 1989: Long-Wave Dynamics of Marginal Zone (in Russian). HydroMeteoIzdat, $272 \mathrm{pp}$.

Walsh, D., I. V. Polyakov, L. A. Timokhov, and E. Carmack, 2007: Thermohaline structure and variability in the eastern Nansen Basin as seen from historical data. J. Mar. Res., 65, 685-714.

Walsh, J. E., and W. L. Chapman, 2001: 20th-century sea-ice variations from observational data. Ann. Glaciol., 33, 444-448.

Woodgate, R. A., K. Aagaard, R. D. Muench, J. Gunn, G. Bjork, B. Rudels, A. T. Roach, and U. Schauer, 2001: The Arctic Ocean boundary current along the Eurasian slope and the adjacent Lomonosov Ridge: Water mass properties, transports and transformations from moored instruments. DeepSea Res. I, 48, 1757-1792.

Zhang, J., R. W. Lindsay, M. Steele, and A. Schweiger, 2008: What drove the dramatic retreat of arctic sea ice during summer 2007 ? Geophys. Res. Lett., 35, L11505, doi:10.1029/2008GL034005. 